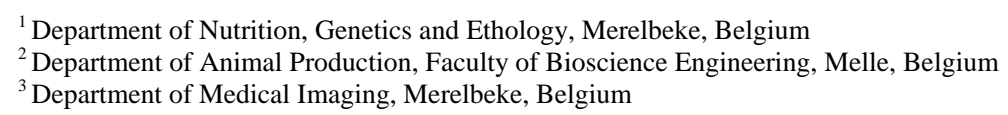

\title{
Parameters for the estimation of live weight and for the visual appraisal of the muscular conformation in the (double-muscled) Belgian Blue beef breed
}

\begin{abstract}
In the double-muscled Belgian Blue beef breed, withers height and hearth girth are routinely measured. This is mainly done to prevent a decrease in growth potential when selecting for increased muscular conformation. The muscular conformation itself is subjectively scored. It was questioned if additional body measurements may improve the accuracy of estimating live weight and whether some of these body measurements may yield information for evaluating the muscular conformation hence the slaughter value of a live animal. It was found that hearth girth and shoulder width have a high correlation with the live weight of slaughter bulls. The width of the hind quarters and withers height are good estimators as well. Models combining these different traits to estimate live weight have reliability up to $83 \%$. Shoulder width and width of the hind quarters are a good reflection of the value of the slaughter bull, which is expressed as Euro per kg cold carcass weight. The withers height is negatively correlated $(r=-0.40)$ with the muscular conformation of the slaughter bulls. Hearth girth has no clear relation with the muscular conformation. The four body traits, withers height, hearth girth, shoulder width and width of hind quarters are interesting traits related to economical traits in the double-muscled Belgian Blue beef breed. Using these body measurements in selection might be worthwhile to consider.
\end{abstract}

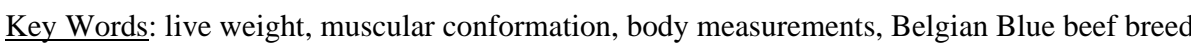

\section{Zusammenfassung}

Titel der Arbeit: Parameter für die Schätzung des Lebendgewichtes und die visuelle Beurteilung des Muskelanteils bei der Blau-Weißen Belgischen Rinderrasse (mit doppelter Muskelmasse)

Bei der Blau-Weißen Belgischen Rinderrasse mit doppelter Muskelmasse werden die Widerristhöhe und der Herzumfang routinemäßig gemessen. Dies geschieht in erster Linie, um einem Rückgang des Wachstumspotenzials vorzubeugen, wenn man sich für einen erhöhten Muskelanteil entscheidet. Der Muskelanteil selbst wird subjektiv bewertet. Man hat sich die Frage gestellt, ob zusätzliche Körpermesswerte die Präzision der Gewichtsabschätzung verbessern könnten und ob einige dieser Körpermesswerte Informationen zur Bewertung des Lebendgewichtes und somit des Schlachtwertes von Lebendtieren liefern könnten. Es hat sich herausgestellt, dass der Herzumfang und die Schulterbreite einen weitgehenden Zusammenhang zum Lebendgewicht von Schlachtbullen aufweisen. Die Breite der Hinterviertel und die Widerristhöhe erlauben ebenfalls eine gute Schätzung. Modelle, die diese verschiedenen Eigenschaften zur Abschätzung des Lebendgewichtes kombinieren, weisen eine Zuverlässigkeit bis zu 83\% auf. Die Schulterbreite und die Breite der Hinterviertel sind ein guter Anhaltspunkt für den Wert von Schlachtbullen, der in Euro pro kg kaltem Schlachtkörpergewicht ausgedrückt wird. Die Widerristhöhe weist eine negative Korrelation $(r=-0,40)$ zur Muskelmasse eines Schlachtbullen auf. Der Herzumfang weist keine deutliche Beziehung zur Muskelmasse auf. Die vier Körpereigenschaften Widerristhöhe, Herzumfang, Schulterbreite und Breite der Hinterviertel sind von Interesse für die wirtschaftlichen Eigenschaften der Blau-Weißen Belgischen Rinderrasse mit doppelter Muskelmasse. Es könnte in Erwägung gezogen werden, diese Körpermaße bei der Auswahl anzuwenden.

Schlüsselwörter: Lebendgewicht, Muskelanteil, Körpermaße, Blau-Weiße Belgische Rinderrasse 


\section{Introduction}

In the double-muscled Belgian Blue beef breed (DM-BBB), body traits such as withers height and hearth girth are gathered on a routine base. The measured heart girth is used to estimate the live weight of yearlings $\left(\mathrm{LW}=0.0005691 *(\mathrm{HG})^{2.607}\right.$; CLAUWERS et al., 1999). This estimated live weight is then used to estimate the economical index (Ec-In) that ranks artificial insemination sires and that reflects their genetic economic value. The withers height of yearling calves is measured as well and used to calculate estimated breeding values for withers height (LEROY and MICHAUX, 1999). The general idea of measuring withers height is to prevent this breed will lose its growth potential and to make sure final weight of the animals remains satisfactory (HANSET et al., 1990). HANSET et al. (1988) showed a strong relationship between weight and withers height in this breed.

No other measurements are considered. The assessment of slaughter value of the yearlings, another economical important trait, that is used to estimate the Ec-In as well, is the result of a visual appraisal. It is expressed as Euro per kg live weight as if the animal would be sold for slaughter at the moment it is scored (GENGLER et al., 1995).

A question that arises is whether additional important body traits should be considered in DM-BBB selection. Older literature data report on good relationships of live weight (LW) with other body traits (VOS, 1969). On the other hand, visual appraisals and the visual classification of traits seem not to be very accurate (ORME et al., 1959). Objective (linear) measurements are described as being good alternatives for visual appraisal of beef type, carcass characteristics and conformation scores (BROWN et al., 1950; ORME et al, 1959; TALLIS et al., 1959; JANSEN et al., 1985; KMET et al., 2000; MARLE-KÖSTER et al., 2000). Therefore the question might be restricted to whether there are body measurements that can help improving the estimation of LW and whether some of them are interesting tools to evaluate the slaughter value of a live animal.

The aim of this report is to provide some background information on the relationship between body measurements and traits that are of economical importance in DM-BBB breeding. Based on the results and conclusions of this preliminary investigation, implementation of body traits other than withers height and hearth girth, might be considered in the selection of the DM-BBB.

\section{Animals}

Materials and methods

During July, August and September of 1996, a group of animals ( $\mathrm{N}=224$; males) was selected at one abattoir (Verbist Izegem; Belgium). Animals were between 449 and 996 days of age and belonged to the Belgian Blue beef breed. The two inspectors who measured the animals evaluated the double muscled phenotype visually. Only doublemuscled animals were considered. Therefore it was concluded that all animals were DM-BBB animals.

\section{Collection of raw data}

The bulls were placed on an electronic balance and live weight was registered. Eleven body conformation traits were recorded on the animals using a measuring rod and tape: 
1. withers height $(\mathrm{WH})$;

2. the external distance between the most lateral points of the tuber coxae (TcTc);

3. shoulder width (SW), the distance between the broadest points of the shoulder;

4. width of the hind quarters $(\mathrm{BcW})$, the distance between the broadest points of the hind quarters;

5. heart depth (HD);

6. the length of the back (LB), measured from the first vertebra of the tail up to the point that's directly behind the line cutting the elbow perpendicular;

7. thickness of the skin (TS), measured on the chest behind the shoulder;

8. thickness of the tail (TT), measuring the broadest distance at the fifth vertebra of the tail;

9. heart girth (HG), measured right behind the shoulders, being half of the heart girth following the muscles on the thorax and then multiplied by two;

10. most narrow circumference of the front long bone (FLB) and

11. most narrow circumference of the rear long bone (RLB).

After the bulls had been measured, they were slaughtered. Before chilling, the carcass was scored according to the SEUROP classification (ANONYMOUS, 1991; conformation class $\mathrm{S}=$ extreme muscularity to $\mathrm{P}=$ poor; fat class $1=$ low fat covering to 5 = extremely fat) and weighed (warm carcass weight; WCW). Additional weighing was done 48 hrs after slaughter (cold carcass weight; CCW). Birth date, slaughter date, value of the cold carcass (Euro per kg cold carcass weight) being the mean values paid by 16 Belgian abattoirs in the year 1996 per SEUROP class, were gathered as well.

\section{Calculated data}

Some of the live body measurements were combined in order to derive a muscular conformation trait that could replace the financial value of the animal estimated by visual inspection. A first muscular conformation trait $\left(\mathrm{MCT}_{1}\right)$ was designed as proposed by HANSET and MICHAUX (1985). According to these authors, a high HG/WH is typical for beef breeds. Two variants on this muscular conformation trait were designed; $\mathrm{MCT}_{2}=\mathrm{BcW} / \mathrm{WH}$ and $\mathrm{MCT}_{3}=\left(\mathrm{HG}^{*} \mathrm{BcW}\right) / \mathrm{WH}$. The width of the hindquarters was used as an alternative because ORME et al. (1959) found significant correlations of 0.4 to $0.5(\mathrm{p}<0.05)$ between width measurements and percent primal cuts. Also this body trait is used as a reflection of muscularity by inspectors judging financial value of DM-BBB animals on contests and as part of the progeny test on the farms (LEROY and MICHAUX, 1999).

$\mathrm{MCT}_{1}, \mathrm{MCT}_{2}$ and $\mathrm{MCT}_{3}$ were multiplied with $\mathrm{LW}$ to obtain an objective estimate of the total value of the live animal $\left(\mathrm{TVL}_{1}-\mathrm{TVL}_{2}-\mathrm{TVL}_{3}\right)$. The total value of a slaughter animal (TVS) in this study was the result of CCW * price per kg CCW and is considered as the gold standard.

Age was calculated using the birth date mentioned on the Sanitel identification card and the slaughter date. Average daily weight gain (ADG) was calculated as the final live weight lowered with $45 \mathrm{~kg}$, the average birth weight of DM-BBB calves (LEROY and MICHAUX, 1999) divided by the age ((LW-45)/age).

\section{Statistics}

SPSS 11.0 for Windows was used to explore and analyse the raw and calculated data. Simple correlations and, if needed, weight corrected correlations between all traits considered were calculated. 
Stepwise multiple regression was applied to estimate live weight from a combination of body measurements.

\section{Results}

One hundred and eighty one animals were classified as "S", 31 as "E" and 12 as "U" and "R". Only six animals had fat coverage of 3, all others showed a fat coverage of 2. The mean, maximum, minimum and standard error of all weights, measurements and calculated data are listed in Table 1.

Table 1

Descriptive statistics for the different body traits, age, value per kg cold carcass weight and total value of the slaughter animal (Beschreibende Statistik der verschiedenen Körpermerkmale, des Alters, des Wertes je kg kaltem Schlachtkörpergewicht und des Gesamtwertes des Schlachttieres)

\begin{tabular}{llllll}
\hline Trait & Mean & s.d. & Minimum & Maximum & N \\
\hline WH & 129.1 & 3.83 & 119 & 139 & 224 \\
TcTc & 56.6 & 4.15 & 42 & 67 & 223 \\
SW & 66.8 & 4.18 & 52 & 79 & 224 \\
BcW & 62.5 & 3.64 & 46 & 71 & 224 \\
HD & 72.5 & 3.07 & 61 & 80 & 219 \\
LB & 81.2 & 4.48 & 70 & 95 & 222 \\
TS & 1.2 & 0.18 & 0.8 & 1.7 & 214 \\
TT & 7.4 & 0.62 & 6.2 & 10.6 & 214 \\
HG & 203.3 & 7.40 & 178 & 226 & 217 \\
FLB & 22.6 & 1.00 & 20 & 25.5 & 213 \\
RLB & 24.1 & 1.00 & 22 & 26.5 & 216 \\
LW & 699 & 47.1 & 476 & 864 & 224 \\
WCW & 465.3 & 54.4 & 307.0 & 585 & 218 \\
CCW & 451.5 & 53.0 & 298 & 577 & 218 \\
Age (days) & 661 & 173.3 & 449 & 996 & 212 \\
ADG (kg/day) & 1.01 & 0.19 & 0.58 & 1.66 & 212 \\
P (Euro) & 3.47 & 0.24 & 2.52 & 3.56 & 157 \\
TVS (Euro) & 1570.18 & 124.20 & 1434.06 & 2056.82 & 217 \\
\hline WH & & & & & \\
\hline
\end{tabular}

$\mathrm{WH}=$ withers height; TcTc = the external distance between the most lateral points of the tuber coxae; SW = shoulder width, the distance between the broadest points of the shoulder; $\mathrm{BcW}$ = width of the hind quarters, the distance between the broadest points of the hind quarters; $\mathrm{HD}=$ heart depth; $\mathrm{LB}=$ the length of the back, measured from the first vertebra of the tail up to the point that's directly behind the line cutting the elbow perpendicular; TS = thickness of the skin, measured on the chest behind the shoulder; TT $=$ thickness of the tail, measuring the broadest distance at the fifth vertebra of the tail; HG = heart girth, measured right behind the shoulders, being half of the heart girth following the muscles on the thorax and then multiplied by two; FLB = most narrow circumference of the front long bone; RLB = most narrow circumference of the rear long bone; WCW = warm carcass weight; CCW = cold carcass weight; ADG = average daily weight gain; $\mathrm{P}=$ price per $\mathrm{kg}$ cold carcass weight; TVS = total value of the slaughter animal.

Table 2

Simple correlations between the live body measurements (Einfache Korrelationen zwischen den Lebend-Körpermesswerten)

\begin{tabular}{|c|c|c|c|c|c|c|c|c|c|c|c|}
\hline Trait & LW & WH & ТсTс & SW & $\mathrm{BcW}$ & HD & LB & $\mathrm{TS}$ & $\mathrm{TT}$ & HG & FLB \\
\hline$\overline{\mathrm{WH}}$ & $0.63^{*}$ & & & & & & & & & & \\
\hline ТсТс & $0.60^{*}$ & $0.28^{*}$ & & & & & & & & & \\
\hline SW & $0.78^{*}$ & $0.33^{*}$ & $0.61^{*}$ & & & & & & & & \\
\hline $\mathrm{BcW}$ & $0.63^{*}$ & $0.24^{*}$ & $0.75^{*}$ & $0.70^{*}$ & & & & & & & \\
\hline HD & $0.62^{*}$ & $0.53^{*}$ & $0.42^{*}$ & $0.37^{*}$ & $0.38^{*}$ & & & & & & \\
\hline LB & $0.40^{*}$ & $0.39^{*}$ & 0.09 & $0.20^{*}$ & 0.03 & $0.32^{*}$ & & & & & \\
\hline TS & 0.12 & -0.02 & -0.03 & 0.00 & -0.08 & 0.12 & $0.19^{*}$ & & & & \\
\hline TT & $0.20^{*}$ & 0.11 & -0.08 & 0.05 & -0.06 & $0.20^{*}$ & $0.32^{*}$ & $0.30^{*}$ & & & \\
\hline $\mathrm{HG}$ & $0.80^{*}$ & $0.50^{*}$ & $0.36^{*}$ & $0.65^{*}$ & $0.44^{*}$ & $0.54^{*}$ & $0.44^{*}$ & $0.17^{* *}$ & $0.28^{*}$ & & \\
\hline FLB & $0.46^{*}$ & $0.37^{*}$ & 0.10 & $0.26^{*}$ & 0.13 & $0.33^{*}$ & $0.19^{*}$ & 0.04 & $0.27^{*}$ & $0.37^{*}$ & \\
\hline RLB & $0.43^{*}$ & $0.42^{*}$ & $0.18^{*}$ & $0.22^{*}$ & $0.18^{*}$ & $0.36^{*}$ & $0.21^{*}$ & -0.02 & $0.19^{*}$ & $0.35^{*}$ & $0.65^{*}$ \\
\hline
\end{tabular}

Trait abbreviations see table $1{ }^{*}=\mathrm{p}<0.05$ and $^{* *}=\mathrm{p}<0.01$. 
of data correction and lack of sufficient information that was provided by the slaughterhouse, some data are missing.

The significant phenotypic correlations between the different data are listed in Table 2, 3 and 4.

Table 3

Simple and weight corrected correlations between the live body measurements, muscular conformation traits and total value of the live animal with the total value of a slaughter animal (TVS) and the price paid per kg cold carcass weight (P) (Einfache und nach dem Gewicht korrigierte Korrelationen zwischen den LebendKörpermesswerten, den Merkmalen des Muskelanteils und dem Gesamtwert des lebenden Tiers sowie dem Gesamtwert des Schlachttieres (TVS) und dem gezahlten Preis je kg kaltem Schlachtkörpergewicht (P))

\begin{tabular}{|c|c|c|c|c|c|c|c|c|c|}
\hline Trait & WH & $\mathrm{WH}^{\mathfrak{f}}$ & SW & $\mathrm{SW}^{£}$ & $\mathrm{BcW}$ & $\mathrm{BcW}^{\mathrm{f}}$ & HG & $\mathrm{HG}^{\mathrm{E}}$ & $\mathrm{HD}^{\mathfrak{E}}$ \\
\hline TVS & $0.40 *$ & $-0.40 *$ & $0.82 *$ & & $0.65^{*}$ & & $0.77^{*}$ & & \\
\hline $\mathrm{P}$ & & & $0.50 *$ & $0.48 *$ & $0.46^{*}$ & $0.43^{*}$ & $0.31 *$ & $-0.14 *$ & $-0.15^{*}$ \\
\hline
\end{tabular}

Trait abbreviations see table $1 ; £=$ weight corrected; ${ }^{*}=\mathrm{p}<0.05$ and ${ }^{* *}=\mathrm{p}<0.01$;

Table 4

Simple and weight corrected correlations between the muscular conformation traits (MCT) and total value of the live animal (TVL) with the total value of a slaughter animal (TVS) and the price paid per kg cold carcass weight (P) (Einfache und nach dem Gewicht korrigierte Korrelationen zwischen den Merkmalen des Muskelanteils (MCT) und dem Gesamtwert des Lebendtiers (TVL) sowie dem Gesamtwert des Schlachttieres (TVS) und dem gezahlten Preis je kg kaltem Schlachtkörpergewicht (P))

\begin{tabular}{|c|c|c|c|c|c|c|c|c|c|c|}
\hline Trait & $\mathrm{MCT}_{1}$ & $\mathrm{MCT}_{1}{ }^{£}$ & $\mathrm{MCT}_{2}$ & $\mathrm{MCT}_{2}{ }^{£}$ & $\mathrm{MCT}_{3}$ & $\mathrm{MCT}_{3}{ }^{\mathrm{E}}$ & $\mathrm{TVL}_{1}$ & $\mathrm{TVL}_{2}$ & $\mathrm{TVL}_{3}$ & Seurop \\
\hline TVS & $0.45^{*}$ & & $0.51^{*}$ & & $0.74^{*}$ & & $0.89 *$ & $0.84^{*}$ & $0.89 *$ & \\
\hline $\mathrm{P}$ & $0.36 *$ & $0.39 *$ & $0.48 *$ & $0.43 *$ & $0.45^{*}$ & $0.42 *$ & & & & $0.92 * *$ \\
\hline
\end{tabular}

Withers height had a significant $(\mathrm{p}<0.05)$ positive correlation with daily weight gain of 0.52 . When muscular conformation was held constant, this correlation between WH and ADG became 0.61 .

Different models to estimate live weight out of body measurements were obtained. Two such models, one using HG, SW and WH (LW $=-1349.5+3.65 * \mathrm{HG}+8.33 * \mathrm{SW}$ $+5.71 * \mathrm{WH})$ and another one using $\mathrm{SW}, \mathrm{WH}$ and $\mathrm{HD}(\mathrm{LW}=-1180.7+10.8 * \mathrm{SW}+$ $5.50 * \mathrm{WH}+6.16 \mathrm{HD}$ ) predict live weight from body measurements with a reliability of 0.83 and 0.81 and estimation error of $31.0 \mathrm{~kg}$ and $32.9 \mathrm{~kg}$ respectively. Models including other body traits were found as well.

\section{Discussion}

The aim of this report is to provide some background information on the relationship between body measurements and traits that are of economical importance in DM-BBB breeding. The specific aim is to verify whether there are body measurements that allow estimating LW better than HG or WH and whether some of these body measurements might be interesting tools to evaluate the muscular conformation hence the slaughter value of a live animal.

Not all of the measured and weighed slaughter bulls were classified as "S" or " $E$ ", which are the SEUROP classes that are commonly considered to encompass all double-muscled animals. This indicates that visual appraisal of the double-muscled phenotype either in live animals or on carcasses may diverge. Probably some living animals showed a misleading phenotype due to the influence of many favourable polygenes that additionally determine muscularity in cattle. The only good method to be sure about the double-muscled character of the animals considered is molecular genetic testing. Only animals that are homozygous for the mutation at the myostatin 
locus are true double-muscled animals (GROBET et al., 1997; KAMBADUR et al., 1997; KOBOLAC and GOCZA, 2002).

Hearth girth and shoulder width have a correlation with live weight that is clearly higher then the correlation between $\mathrm{WH}$ and $\mathrm{LW}$. Withers height and $\mathrm{BcW}$ have a slightly higher correlation with live weight then HD and TcTc. The correlation of HD with LW is considerably lower then the correlation between HG and LW. Because HD has a comparable relationship with muscular conformation as HG, HD is not an interesting candidate. Withers height and TcTc have a comparable correlation with LW, but WH gives more information on the muscular conformation $(r=-0.40)$ and on daily weight gain $(r>0.5)$. It is therefore more interesting to have information on the WH then on TcTc. The correlations between HG and WH, HG and SW, HG and BcW are positive and significant, but different from 1 . Yet all four body measurements have high and significant correlations with live weight. This might indicate that combining HG with these two body traits to estimate LW can be interesting. A model was found that combines HG, SW and WH and that estimates LW with a reliability of $83 \%$. Comparing the reliability and estimation errors of models based on $\mathrm{HG}$ alone or combined with other body traits, developed with many more data and on different ages, and taking care only pure bred DM-BBB are used, may resolve the question whether one should keep on using the HG only or include also other body traits.

The high correlation between the SEUROP classification and price per kg CCW is logic. It becomes clear out of this small study that SW and BcW are moderately related with the price per kg cold carcass value. Both SW and BcW reflect the muscular conformation of a slaughter animal, expressed as the price per $\mathrm{kg}$ CCW, the best. Hearth girth is no such good reflection of price per $\mathrm{kg}$ as can be concluded out of the weight corrected correlation.

It is interesting that the individual body traits $\mathrm{SW}$ and $\mathrm{BcW}$ measured on a living animal are good reflections of the total carcass value. Especially SW is interesting. It has a higher correlation with TVS then HG with TVS. The good reflection of the TVS by both SW and BcW is not surprising because they do not only reflect muscular conformation (related to price per kg CCW) but also LW. Withers height on its own has not such good relation with this slaughter value because with higher weight due to an increased $\mathrm{WH}$, the animal becomes less muscular and will be paid less per $\mathrm{kg}$ CCW. Although HG on its own does not reflect muscular conformation that well, it has a high correlation with the total slaughter values. This can be explained by the huge correlation between LW and HG. This ascertainment emphasizes the importance of sufficient weight at slaughter age. Muscular conformation is of great importance in the DM-BBB and is a typical characteristic of this breed, but weight at slaughter age is considered relatively more important, especially if this weight is due to muscular conformation (BcW and SW) rather than by size of the animal (WH). The clear increase in correlation between all three MCT values with TVS if multiplied with LW (resulting in the TVL-values) confirms the importance of LW. These considerations reflect the opinion of HANSET et al. (1990) and confirm the results of earlier studies (COOPMAN et al., 1999).

The overall observation of this study is that a better muscled animal, compared to a less muscled animal having the same weight, has a broader width of the hind quarters, width of the tuber coxae and shoulder width. It has a less deep breast, a smaller skin, smaller long bones and tail thickness and a shorter back. Although the animal is 
smaller and has an absolute smaller hearth girth, it has a relatively higher HG/WH ratio. The differences between a better muscled and a lesser muscled animal having the same weight, are especially more clear for $\mathrm{BcW}$ and $\mathrm{SW}$ (better muscled animal broader in shoulder and hind quarters) and WH (better muscled animals are small).

The results showed that withers height (WH), hearth girth (HG), shoulder width (SW) and width of the hind quarters $(\mathrm{BcW})$ are interesting body traits that allow estimating live weight and evaluating muscularity from an economical point of view in the double muscled Belgian Blue Beef breed (DM-BBB). Whereas WH and HG reflect weight related to the size of the animal, SW and $\mathrm{BcW}$ reflect weight related to the muscular conformation of the animal. WH (negatively), SW and BcW (both positively) reflect muscular conformation of the animal as well. Studies at different ages and using these body measurements in combination with the traditional approaches can provide new insights and finally help to improve selection in this double muscled beef breed.

\section{Acknowledgements}

The authors wish to thank Ir F. Florizoone, a former final-year student for his help in collecting the data, and Mr. Verbist for giving permission to collect the data in his slaughterhouse.

ANONYMOUS:

\section{References}

Council regulation (EEC) $\mathrm{N}^{\circ}$ 1026/91 of 22 April 1991 amending Regulation (EEC) $\mathrm{N}^{\circ}$ 1208/81 determining the Community scale for the classification of carcasses of adult bovine animals. (1991) Community legislation in force, Document 391R1026, pp. 1-2

BROWN, C.J.; WARWICK, E.J.; SMITH, H.J.; GREEN W.W.; STEWART, H.A.:

Relationship between conformation scores and live animal measurements of beef cattle. J. Anim. Sci. 15 (1950), 911-921

CLAUWERS, M.; WILLEMS, W.; VANDENBERGHE, K.:

Beef production; Results of Flemish reference farms, part 2 (Dutch). Dienst ontwikkeling dierlijke productie, sector vleesvee. (1999), Brochure van het ministerie van middenstand en landbouw, pp. 1-72

COOPMAN F.; PEELMAN L.J.; VAN ZEVEREN A.:

Correlations and linear regressions between four approaches to assessing the market value of Belgian Blue beef cattle (Dutch). Flem. Vet. J. 68 (1999), 135-141

GENGLER, N.; SEUTIN, C.; BOONEN, F.; VAN VLECK L.D.:

Estimation of genetic parameters for growth, feed consumption and conformation traits for doublemuscled Belgian Blue Bulls performance-tested in Belgium. J. Anim. Sci. 73 (1995), 3269-3273

GROBET, L.; MARTIN, L.J.; PONCELET, D.; PIROTTIN, D.; BROUWERS, B.; RIQUET, J.; SCHOEBERLEIN, A.; DUNNER, S.; MENISSIER, F.; MASSABANDA, J.; FRIES, R.; HANSET, R.; GEORGES, M.:

A deletion in the bovine myostatine gene causes the double - muscled phenotype in cattle. Nat. Gen. 17 (1997), 71-74

HANSET, R.; MICHAUX, C.:

On the genetic determinism of muscular hypertrophy in the Belgian White and Blue cattle breed, II. population data. Gen. Ev. Sel. 17 (1985), 396-386

HANSET, R. ; MICHAUX, C., DETAL, G.:

Une étude sur la croissance de taureaux I.A. de race Blanc-Bleu Belge. Ann. Méd. Vét. 132 (1988), 577-591

HANSET, R.; MICHAUX C.; DETAL, G.; BOONEN F.; LEROY, P.:

Conformation et format dans la selection du Blanc-Blue Belge ; introduction d'un système de cotations linéaires. Ann. Méd. Vét. 134 (1990), 197-204

JANSEN, J.; BECH ANDERSEN, B. ; BERGSTRÖM, P.L.; BUSK, H.; LAGERWEY, G.W.; OLDENBROEK, J.K.:

In vivo estimation of body composition in young bulls for slaughter. 1. The repeatability and reproducibility of a scoring system, an ultrasonic scanning technique and body measurements. Livest. Prod. Sci. 12 (1985), 221-230 
KAMBADUR, R.; SHARMA, M.; SMITH, T.P.L.; BASS, J.J.:

Mutations in myostatin (GDF8) in double-muscled Belgian blue and Piedmontese cattle. Genome Res. 7 (1997), 910-915

KMET, J.; SAKOWSKI, T.; HUBA,J.; PESKOVICOVA, J.; CHRENEK, J.; POLAK, P.:

Application of video image analysis in the slaughter value estimation of live Simmental bulls. Arch. Tierz., Dummerstorf 43 (2000), 411-416

KOBOLAK, J.; GOCZA, E.:

The role of the myostatin protein in meat quality - a review. Arch. Tierz., Dummerstorf 43 (2002), 159170

LEROY, P; MICHAUX, C.:

1999. The double muscled Belgian blue beef breed; results of progeny testing on farms of A.I. sires (Dutch-French). In Herd-book du Blanc-Bleu Belge; XXIII ${ }^{\mathrm{e}}$ report. (1999), Convention I.R.S.I.A. 5614A, pp. 1-36

MARLE-KÖSTER van, E.; MOSTERT, B.E.; WESTHUIZEN van der, J.:

Body measurement as a selection criteria for growth in South African Hereford cattle. Arch. Tierz. 43 (2000), 5-15

ORME, L.E.; PEARSON, A.M.; MAGEE, W.T.; BRATZLER, L.J.:

Relationship of live animal measurements to various carcass measurements in beef. J. Anim. Sci. 18 (1959), 991-999

TALLIS, G.M.; KLOSTERMAN, E.W.; CAHILL, V.R.:

Body measurements in relation to beef type and to certain carcass characteristics. J. Anim. Sci. 18 (1959), 108-115

VOS, M.P.M.:

Measuring and weighing beef cattle (Dutch). Reports of agricultural research $\mathrm{N}^{\circ}$ 729. (1969),

Wageningen, The Netherlands, center for agricultural publications and documentation, pp 1-122

Received: 2007-01-08

Accepted: 2007-03-22

Authors' addresses

Dr. FRANK COOPMAN*, Prof. Dr. ALEX VAN ZEVEREN

Department of Nutrition, Genetics and Ethology,

Faculty of Veterinary Medicine,

Ghent University,

Heidestraat 19,

B-9820 MERELBEKE, BELGIUM

*Corresponding Author; E-Mail: N_C_S_A@hotmail.com

Dr. GEERT VERHOEVEN

Department of Medical Imaging,

Faculty of Veterinary Medicine,

Ghent University,

Salisburylaan, 133,

B-9820 MERELBEKE, BELGIUM

Prof. Dr. Ir. STEFAAN DE SMET

Department of Animal Production,

Faculty of Bioscience Engineering,

Ghent University,

Proefhoevestraat 10,

9090 MELLE, BELGIUM 